PRZEGLĄD NAUK HISTORYCZNYCH 2017, R. XVI, NR 1

http://dx.doi.org/10.18778/1644-857X.16.01.12

MirosŁaW Romański

Politechnika Rzeszowska*

\title{
„Wiekowy spór” - Boliwia a dostęp do morza
}

\section{Podłoże konfliktu chilijsko-boliwijskiego i próby jego rozwiązania}

7 ak zwany konflikt o saletrę, określany w literaturze częstokroć jako wojna o saletrę czy wojna saletrzana, przebiegał w latach 1879-1884. Wzięły w nim udział Chile przeciwko połączonym siłom Boliwii i Peru. W sporze chodziło głównie o zdobycie przez Chile terenu, na którym znajdowały się wówczas surowce mineralne. Wiązały się $z$ tym zabiegi o odcięcie dostępu Boliwii do Pacyfiku, na co $z$ kolei zareagowało sąsiednie Peru ${ }^{1}$.

Bogata w pokłady saletry (łac. sal petri-sól skalna) część pustyni Atakama jest terenem znajdującym się między 23 i 25 równoleżnikiem przy wybrzeżu Oceanu Spokojnego. W czasie konfliktu saletra była pożądanym surowcem służącym przede wszystkim jako składnik do produkcji materiałów wybuchowych i pirotechnicznych. Bezpośrednim impulsem do przekształcenia się sporu dyplomatycznego w wojnę było podwyższenie podatku przez Boliwię dla firm chilijsko-brytyjskich, które zajmowały się wydobywaniem saletry. Od tej pory Chile i Boliwia rościły sobie prawo do przynajmniej częściowego posiadania terenu pustyni Atakama².

Prageneza konfliktu niezbicie dowodzi, że Chile miało prawo czuć się oszukane. W dniu 6 sierpnia 1874 r. zawarło bowiem porozumienie $z$ Boliwią, na mocy którego zrzekło się części pustyni Atakama

*Wydział Zarządzania, Zakład Nauki o Bezpieczeństwie, e-mail: mirmur2@o2.pl.

${ }^{1}$ B. Ronald, The Bolivia-Chile-Peru Dispute in the Atacama Desert. Boundary and territory briefing, vol. I, No. 6, Durham 1994, s. 4; W. Sater, Chile and the War of the Pacific, Nebraska 1986, s. 11.

${ }^{2}$ R. Talb ott, A History of the Chilean Boundaries, Ames 1974, s. 34. 
powyżej 24 równoleżnika w zamian za nienakładanie podatków na działajace na tym terenie firmy chilijskie. W 1879 r. Boliwia zerwała jednak to porozumienie i za namowa Peru, które chciało znacjonalizować złoża i produkcję saletry w prowincji Tarapacá (będących własnością chilijska), zawarła $z$ nim tajny sojusz. Peru znacjonalizowało wówczas złoża, a Boliwia nałożyła podatki na kampanię chilijska. W reakcji na to 14 lutego 1879 r. Chile zajęło Antofagastę, a 5 kwietnia wypowiedziało wojnę koalicji boliwijsko-peruwiańskiej. Zatem historyczne racje niekoniecznie jednoznacznie leżą po stronie Boliwii, która popełniła błąd, dając się namówić Peru i straciła na tym najwięcej.

Przez prawie 140 lat, bo od 1879 r. do czasów współczesnych, spór saletrzany obfitował $\mathrm{w}$ wiele wydarzeń $z$ początku rokujacych jako korzystne dla obu stron rozwiązanie. Począwszy od podpisania w 1866 r. pierwszego traktatu granicznego między Chile a Boliwia, otwarciu w 1868 r. portu Antofagasta oraz podpisaniu w 1874 r. drugiego traktatu granicznego między Boliwią i Chile, rozpoczął się szereg działań dyplomatycznych zarówno w omawianym regionie, jak i z zaangażowaniem sił międzynarodowych. Po wspomnianym nałożeniu $10 \%$ podatku w 1878 r. przez Boliwię od każdego eksportowanego kwintala saletry (46 kg), a także zajęciu w 1879 r. przez Chile portu w Antofagaście i wypowiedzeniu wojny Boliwii i Peru Chile i Peru podpisały traktat pokojowy w Ancon w 1883 r. Z kolei Boliwia podpisała traktat w Valparaiso już w 1884 r., a w 1887 r. Senat Chile wyraził zgodę na przyłączenie prowincji Antofagasta do tego państwa. Dokonywane w latach następnych działania sprawiły, że Chile i Boliwia podpisały pięć wzajemnych umów w 1895 r. Jednakże ostateczny tekst traktatu pokojowego został przyjęty i podpisany przez obie strony w 1904 r. Boliwia zaproponowała zrewidować ów traktat ${ }^{3}$. Przed I posiedzeniem Ligi Narodów (15 listopada - 18 grudnia 1920 r.) Boliwia zgłosiła swój wniosek - samodzielnie, choć w porozumieniu z Peru - 1 listopada 1920 r. Powołując się na art. 19 Paktu Ligi Narodów, zażądała „rewizji”, a Peru - „ponownego rozważenia i rewizji” traktatów pokojowych zawartych z Chile w 1883 i 1904 r. Za podstawę wniosku wskazano niewykonalność postanowień traktatowych, co miało grozić wybuchem wojny. Sprawą tą nie zajęto się jednak na I posiedzeniu Ligi,

3 The Blue Book. The Maritime Claim of Bolivia, Presidency of the Republic, Ministry of Foreign Affairs, Dirección de Informaciones de la Presidencia de la República, [b.m.] 2004, s. 80-82. 
tylko dopiero na II, ponieważ Peru ostatecznie wycofało swój wniosek. Na zlecenie Zgromadzenia Ligi Narodów 28 września 1921 r. prawnicy $z$ Włoch, Kolumbii i Kostaryki przedstawili opinię, $z$ której wynikało, że żądania Boliwii są bezzasadne, gdyż Zgromadzenie „nie jest władne zmieniać traktaty"4. W reakcji na to Boliwia wycofała swój wniosek.

W 1926 r. w omawiany spór zaangażowały się Stany Zjednoczone. Sekretarz stanu USA Frank Kellogg interweniował wówczas w Chile i Peru. Już wkrótce, bo w 1929 r. w Limie doprowadzono do podpisania traktatu między tymi krajami. Na jego mocy prowincja Arica została przyłączona do Chile, a Tacna - do Peru. Dopiero w 1950 r. Chile i Boliwia wymieniły noty dyplomatyczne $z$ propozycjami rozwiazania sprawy dostępu do morza. Udział $\mathrm{w}$ tych rozmowach od 1951 r. miał także rząd USA z prezydentem Harrym Trumanem.

W 1962 r. po raz pierwszy władze Chile bez porozumienia z Boliwia doprowadziły do zmiany biegu rzeki Lauca płynacej wzdłuż granicy. Spowodowało to zerwanie stosunków dyplomatycznych między obu krajami. Po deklaracji z Ayacucho z 1974 r., uznajacej ograniczenia boliwijskie związane $z$ odcięciem od morza, a także prób rozwiązania kwestii dostępu Boliwii do morza w 1975 r. przez Organizację Państw Amerykańskich, co zbiegło się z upamiętnieniem 150-lecia niepodległości Boliwii, zaczęły się negocjacje Chile $z$ Boliwia określane jako „Embrace of Charana”. Po złożeniu w 1976 r. przez Peru własnej propozycji i odmowie Chile w 1978 r. rozmowy w Charanie ostatecznie zakończyły się fiaskiem, co potraktowane zostało jako zerwanie relacji dyplomatycznych po raz drugi. W związku $z$ tym w 1979 r. zgromadzanie Organizacji Państw Amerykańskich gościło w Boliwii, która zdobyła wówczas poparcie dla rezolucji określającej odcięcie Boliwii od morza jako problemu międzynarodowego. W 1989 r. postanowiono, że odtąd kwestia dostępu Boliwii do morza będzie przedmiotem debat na wszystkich następnych sesjach zgromadzenia ogólnego Organizacji Państw Amerykańskich. Mimo wielu spotkań w latach 2000-2003 rozmowy nie dały rezultatów ${ }^{5}$. $Z$ tego powodu uznaje się, że spór chilijsko-boliwijski o odzyskanie dostępu do morza stanowi jeden $z$ najbardziej rozległych w czasie i nieprzynoszacych konkretnych rezultatów.

${ }^{4}$ S. Sier pows ki, Narodziny Ligi Narodów, Poznań 1984, s. 113.

5 The Blue Book..., s. 80-82. 


\section{Współczesna sytuacja społeczno-polityczna Boliwii i działania dyplomatyczne $w$ regionie}

W Boliwii od stycznia 2006 r. realizowany jest program Ruchu na rzecz Socjalizmu, który związany jest $z$ prezydentem Evo Moralesem, od tamtego czasu rządzącego krajem. Pod koniec 2009 r. w Boliwii przeprowadzono drugie od chwili uchwalenia nowej konstytucji wybory. To ułatwiło Evo Moralesowi ponowne starania o urząd prezydenta Boliwii. Tak jak w 2005 r., w 2009 r. odniósł on sukces wyborczy z poparciem $61 \%$ głosów. Jego Ruch na rzecz Socjalizmu uzyskał 88 miejsc w Izbie Reprezentantów i 25 w boliwijskim Senacie. W taki sposób ugrupowanie utrzymało zdobytą w 2009 r. większość 2/3, która była konieczna do samodzielnej zmiany ustawy zasadniczej. Należy dodać, że najgroźniejszy kontrkandydat Moralesa i zarazem jeden $z$ najbogatszych Boliwijczyków, Samuel Doria Medina, związany z Unia Demokratyczna, uzyskał $24 \%$ głosów. Tylko 3\% poparcia zdobył lewicowy i sprzymierzony z Ruchem na rzecz Socjalizmu (MAS) Ruch bez Strachu (MSM), jak również Partia Zielonych ${ }^{6}$. Gdy Evo Morales został prezydentem, szybko rozpoczą radykalna wymianę dotychczasowych skorumpowanych elit. Tym działaniom towarzyszyły fundamentalne przeobrażenia w sferze polityki, którą często porównywano do rewolucji narodowej w Boliwii z 1952 r. $^{7}$

Przemiany społeczno-polityczne w Boliwii dokonujące się od 2006 r., realizowane dzięki prospołecznej polityce Moralesa, znacznie zredukowały podziały społeczne. W latach 2005-2011 poziom biedy zmniejszył się z $60 \%$ do $45 \%$. Mimo że podstawa gospodarki Boliwii jest przemysł wydobywczy, nadmienione czynniki społeczne wywarły decydujacy wpływ na dynamiczny rozwój rynku wewnętrznego i przyczyniły się do sukcesu gospodarczego Boliwii ${ }^{8}$.

Priorytetowym elementem mającym wpływ na podejmowane $\mathrm{w}$ tym regionie działania dyplomatyczne zarówno w obszarze polityki wewnętrznej, jak i zagranicznej względem sąsiadów i pozostałych państw Ameryki Łacińskiej jest kwestia odzyskania dostępu

\footnotetext{
${ }^{6}$ A. Traczyk, Analiza: Boliwia u progu trzeciej kadencji Evo Moralesa, „Global. Lab" 2015, nr 2 (luty), s. 3.

${ }^{7}$ M. Kula, Anatomia rewolucji narodowej. Boliwia w XX wieku, Wrocław 1999, s. $55-64$.

${ }^{8}$ C. Gouverneur, Boliwia zapatrzona $w$ morskie fale - 136 lat konfliktu, „Monde Diplomatique - miesięcznik społeczno-polityczny” 2015, nr 10, s. 32-35.
} 
do morza przez Boliwię. Dlatego kraj ten stara się utrzymywać przyjazne relacje zagraniczne ze wszystkimi krajami. Jedynym państwem, w stosunku do którego dyplomacja Boliwii pozostawia wiele do życzenia, jest Chile, od którego zależy dostęp do akwenu. Zatem stosunki dyplomatyczne Boliwii z Chile sa, delikatnie mówiąc, dalekie od normalności ${ }^{9}$.

Mimo takiego stanu rzeczy Boliwia aktywnie prowadzi działania dyplomatyczne. W 1993 r. podpisała $z$ Chile umowy dotyczace zniesienia barier celnych oraz popierania wzajemnych inwestycji. Rok wcześniej stojące po stronie Boliwii w wojnie saletrzanej Peru zezwoliło Boliwii na stworzenie strefy wolnego handlu w peruwiańskim mieście $\mathrm{Ilo}^{10}$. Budowanie przyjaznych relacji $z$ państwami regionu potwierdza wynegocjowanie i podpisanie w 1994 r. z Brazylia kontraktu o powstaniu gazociagu wiodacego do południowej i południowo-wschodniej części tego kraju ${ }^{11}$.

Postawa dyplomacji Boliwii sprawia, że państwo jest aktywnym członkiem wszystkich organizacji skupiających kraje Ameryki Południowej. Należy też do Organizacji Narodów Zjednoczonych, Unii Międzyparlamentarnej, Światowej Organizacji Handlu, Ruchu Państw Niezaangażowanych, Stowarzyszenia Integracji Latynoamerykańskiej, Andyjskiego Rynku Wspólnego i Intelsatu ${ }^{12}$.

W 1998 r. Bank Światowy razem z Międzynarodowym Funduszem Walutowym umorzyli Boliwii część długu międzynarodowego, który opiewał na kwotę 760 mln dolarów. Boliwia jako kraj realizujący aktywną dyplomację zagraniczną $z$ dynamicznie rozwijająca się infrastrukturą dostała 1,2 mld dolarów od Banku Światowego w 2011 r. Również USA przekazały Boliwii wsparcie finansowe w 2004 r. w postaci 150 mln dolarów ${ }^{13}$. Natomiast po objęciu władzy w Boliwii przez Evo Moralesa kraj otrzymał od Hiszpanii 99 mln euro w ramach umorzenia części długów.

${ }^{9} \mathrm{~K}$. Cholewiń s ka, Czy reindianizacja państwa jest możliwa? Etnocentryczne projekty we współczesnej Boliwii, „Ameryka Łacińska - kwartalny biuletyn informacyjno-analityczny" 2014, R. XXII, s. 74-86.

10 J.M. Fij or, Boliwia już czerwona, kto następny?, „Najwyższy Czas! - pismo konserwatywno-liberalne" 2003, nr 47, s. XX-XXI.

11 Ibidem.

12 P. Kułak, Międzynarodowy Trybunał Karny, „Annales Universitatis Mariae Curie-Skłodowska. Sectio K - Politologia” 2008, vol. XV, z. 1, s. 37-55.

${ }^{13} \mathrm{R}$. W ordliczek, Ewolucja w stosunkach boliwijsko-amerykańskich na przeŁomie XX i XXI w., „Ameryka Łacińska - kwartalny biuletyn informacyjno-analityczny" 2015, R. XXIII, nr 2, s. 66-90. 
W 2005 r., po spotkaniach dyplomatycznych Boliwii z Wenezuela i Kuba, Evo Morales z prezydentami Hugo Chavezem i Fidelem Castro utworzyli antyamerykański front opierający się na bogactwie surowców naturalnych. Wówczas wydano dekret o nacjonalizacji przemysłów gazowego i naftowego, a także zerwano rozmowy odnośnie do wolnego handlu $z$ USA i Unią Europejska. Inicjatywy dyplomacji Boliwii doprowadziły w 2012 r. do podpisania protokółu akcesyjnego do Wspólnego Rynku Południa. Zagwarantował on Boliwii członkostwo w tej regionalnej organizacji gospodarczej. Należą do niej: Wenezuela, Paragwaj, Argentyna, Brazylia i Urugwaj ${ }^{14}$.

Od 2006 r. Boliwia przeszła rewolucyjne przemiany w swojej polityce wewnętrznej. Gospodarkę cechuje dynamiczny skok, budżet kraju zaś wzrósł o kilkaset procent. Działania dyplomatyczne pociagające za soba zawieranie rozmaitych umów, wstępowanie do organizacji, prowadzenie dialogu $z$ sasiadami, a także zadbanie o wewnętrzne przemiany społeczno-kulturowe mają swój efekt. W Boliwii bowiem na przestrzeni ubiegłych lat udało się wprowadzić na ogól niespotykaną w historii tego państwa stabilizację ${ }^{15}$.

Działania dyplomatyczne Boliwii podejmowane od dojścia do władzy w 2005 r. Evo Moralesa sa dosyć złożone i skomplikowane. Napięcia społeczne w tym państwie dotycza głównie kwestii bytowych, socjalnych i kluczowej sprawy odzyskania dostępu do obszaru morskiego. W obszarze polityki dyplomacji skierowanej na działania zewnętrzne od 2005 r. Boliwia odnosi w zasadzie same sukcesy. Większość podpisanych przez nią umów przynosi ogromne korzyści. Praktycznie każde $z$ państw sąsiadujących jest $z$ Boliwią w dobrych stosunkach. Kula u nogi jest jedynie ciagnąca się od lat sprawa uzyskania dostępu do obszaru morskiego i konflikt $z$ Chile.

\section{Starania Boliwii o odzyskanie dostępu do morza}

Po upłynięciu 127 lat od oficjalnego zakończenia wojny chilijsko-boliwijskiej, w której Boliwię wspierało Peru, prezydent Evo Morales zabiegał o zrewidowanie granic obu państw, co miałoby pozwolić na odzyskanie przez kraj, którym rządzi, dostępu do Oceanu

\footnotetext{
${ }^{14}$ A. Traczyk, Boliwia-zastygła rewolucja?, „Dziennik Opinii” 2016, nr 50, s. 3-5.

15 Ibidem.
} 
Spokojnego ${ }^{16}$. Mimo że od konfliktu upłynęło wiele lat, dążenie do odzyskania dostępu do terytorium morskiego nadal jest priorytetowym elementem polityki Boliwii, bez względu na to, jaka opcja polityczna sprawuje władzę ${ }^{17}$.

Boliwia to państwo o dosyć specyficznych uwarunkowaniach politycznych. Sytuację w tym kraju od początku jego istnienia charakteryzuje niestabilność. Niemały wpływ na taki stan rzeczy miały i maja zamachy stanu stanowiące nieodłaczony element wizerunku politycznego kraju. Od 1870 r. dokonano w Boliwii aż 190 puczów, tzn. władza zmieniała się na ogół dwa razy w roku. Trzeba też zauważyć, że kraj ów stoczył cztery wojny, z których wszystkie przegrał, a rezultaty konfliktu o Pacyfik odczuwane sa do dziś. Należy jednak pamiętać, że pronunciamento jest na trwałe wpisane w kulturę polityczną i historię byłych hiszpańskich kolonii, także samej Hiszpanii ${ }^{18}$.

Odzyskanie dostępu do terenu morskiego Boliwijczycy uznają za zadanie priorytetowe i wręcz obowiązkowe. W tym względzie próbowano różnych metod osiagnięcia założonego celu. Negocjowano $z$ władzami chilijskimi i proszono o wsparcie na poziomie międzynarodowym. Czyniono nawet starania o wybudowanie specjalnego tunelu o długości 150 km, który miał prowadzić przez część północną Chile pod granica z Peru, wiodac do sztucznej wyspy na Pacyfiku. W czasach współczesnych, gdy sprawa nadal nie jest wyjaśniona, wielu badaczy, polityków i obserwatorów międzynarodowych twierdzi, że Boliwia nie ma żadnych podstaw, by domagać się dostępu do morza. Jednakże takie podejście sprawia, że obszar ten pozostaje punktem zapalnym w stosunkach Chile-Boliwia. Od 1978 r., gdy Boliwia zerwała dyplomatyczne relacje $z$ Chile, dażenie do tego, aby odzyskać sporny teren, określa się mianem „marcha al mar” ${ }^{19}$.

Sytuacja się nieco zmieniła, odkąd prezydent Chile Michelle Bachelet wysłał zaproszenie do prezydenta Boliwii Evo Moralesa na uroczystość objęcia przez siebie urzędu. Morales przyjął zaproszenie, majac przy okazji nadzieję na możliwość prowadzenia dalszych rozmów w sprawie istotnej dla Boliwii. Od tego spotkania relacje między krajami wyraźnie się polepszyły. Nawet w Ministerstwie

16 C. Gouverneur, op. cit., s. 32-35.

17 Ibidem, s. 33.

18 T. Skowronek, Boliwijska walka o dostep do oceanu, „Biuletyn Europejskiego Centrum Analiz Geopolitycznych", 4 V 2013, s. 1-2.

19 J.M. Fijor, op. cit., s. XX-XXI. 
Spraw Zagranicznych Chile powołano specjalistyczna grupę, której celem było przywrócenie stosunków dyplomatycznych $z$ sąsiadem. W rozmowach poruszano ogół problemów, wśród nich oddanie Boliwii skrawka wybrzeża. Jednak patrzac realnie, jest mało prawdopodobne, aby liczace ok. 200 tys. ludności miasto Arica stało się na nowo własnością Boliwii. W Chile planowano też wybudować całkowicie nowe miasto i port, które miałyby stanowić boliwijska enklawę nad Oceanem Spokojnym. Uzyskano również potwierdzenie prezydenta Peru Alana Garcii, że zaakceptuje on każde wypracowane przez Boliwię i Chile rozwiązanie ${ }^{20}$.

Co prawda w 2010 r. Peru przyznało Boliwii dostęp do morza po podpisaniu na 99 lat umowy dzierżawnej, ale dla Boliwii umowa nie jest w pełni zadowalająca. Władze kraju są zdania, że nieograniczony dostęp do terenu morskiego wiązałby się $z$ szerszymi możliwości dla rozwoju handlu Boliwii $z$ wieloma państwami. Dzięki temu kraj miałby możliwość realizacji planów stworzenia własnego portu i bazy wojskowej.

Również eksprezydent Boliwii Jorge Quiroga zaproponował obecnemu rządowi, aby zwrócił się $z$ prośba do papieża Franciszka o udział w rozmowach na temat spornej kwestii. Rozmaite próby zbliżenia między Chile i Boliwią na gruncie politycznym kończą się na ogół fiaskiem, więc kraje utrzymuja ze sobą tylko relacje konsularne. Zdaniem władz w La Paz państwa, które nie maja dostępu do terenu morskiego, nie rozwijaja się $z$ taką dynamika, jak gospodarki państw mających takowy dostęp. Stwierdzenie, że dla Boliwii dostęp do morza otwierałby nowe możliwości i perspektywy, a oprócz dynamiki rozwoju w obszarze handlu zaistniałaby możliwość stworzenia bazy turystycznej, wydaje się czysto propagandowa zagrywką na użytek wewnętrzny - zwłaszcza wobec występujących napięć społecznych ${ }^{21}$.

W 2011 r. prezydent Boliwii Evo Morales usiłował rozwiązać problem dostępu do morza $z$ udziałem międzynarodowych trybunałów. Jednak nie wiązało się to $z$ działaniami ukierunkowanymi na satysfakcjonujące rozstrzygnięcie konfliktu ${ }^{22}$. Po złożeniu przez Moralesa pozwu przeciwko Chile do Międzynarodowego Trybunału Sprawiedliwości chilijski minister spraw zagranicznych Alfredo Moreno powiedział, że oczekuje na wyrok w pełnym spokoju, bo

\footnotetext{
${ }^{20}$ R. Wordliczek, op. cit., s. 66-90.

${ }^{21}$ C. Gouverneur, op. cit., s. 32-35.

${ }^{22}$ K. Cholewińska, op. cit., s. 74-86.
} 
jego rząd jest w dyspozycji traktatu o przyjaźni i pokoju z 1904 r., który został zawarty zgodnie $z$ prawem międzynarodowym i rozwiewa ogół wątpliwości co do istniejącego sporu. Strona boliwijska $z$ kolei sądzi, że o ile traktat ów został podpisany, to jednak pojawiły się naciski na Boliwię ze strony Chile do jego akceptacji zaraz po wygaśnięciu działań wojennych. Boliwijski prezydent Evo Morales stwierdził, że jego kraj nigdy nie zaakceptuje utraty dostępu do terenu morskiego $z$ lat 1879-1884. W efekcie wojny saletrzanej o Pacyfik władze Chile przeprowadziły aneksję dwóch położonych koło brzegu prowincji - Litoral w Boliwii i Tarapacá w Peru. Zagwarantowało to powiększenie swego obszaru i uzyskanie lepszej kontroli nad wybrzeżem Pacyfiku ${ }^{23}$. Morales określił stratę obfitującej w surowce mineralne prowincji jako „otwarta rana”, która niestety się nie zabliźni, jeśli nie przywróci się status quo ante bellum. Podczas przemówienia w La Paz mówił, że starania o odzyskanie dostępu morskiego powinny współcześnie przebiegać $z$ uwzględnieniem nowych realiów, czyli domagania się swoich roszczeń przez trybunały międzynarodowe oraz organizacje wolnego i suwerennego dostępu do morza ${ }^{24}$. Odpowiedź prezydenta Chile Sebastiana Pinery przyszła dość szybko. Roszczenia władz boliwijskich uznał za trudne do przyjęcia, odrzucając żądania Moralesa. Stosunki obu krajów, pogorszone od 1978 r. - po zerwaniu przez Boliwię stosunków dyplomatycznych $z$ Chile - wywołane były tylko i wyłącznie pretensjami terytorialnymi. Niemniej jednak w 2013 r. stwierdzono, że powstałe na tle tego sporu antagonizmy między Chile a Boliwią moga się pogłębić. We wrześniu 2013 r. Komisja Spraw Zagranicznych Kongresu peruwiańskiego zatwierdziła „porozumienie Boliviamar”, które gwarantuje Boliwii dostęp do części wybrzeża od Peru. Boliviamar leży na południu kraju, ok. $17 \mathrm{~km}$ od miasta Ilo, na skrawku plaży o długości $160 \mathrm{~km}^{25}$.

Nie zważając na niepowodzenia, władze Boliwii wciąż starają się dowieść swoich racji terytorialnych. Dowodem było przedstawienie ich w Hadze 17 kwietnia 2014 r., gdzie ogłoszono, że odzyskanie spornego obszaru ma swe uzasadnienie historyczne, prawne i moralne. Liczono na to, że prezentacja będzie miała decydujące

${ }^{23}$ R. Burr, By Reason or Force: Chile and the Balancing of Power in South America 1830-1905, Berkeley-Los Angeles 1967, s. 181-183, 190-191.

${ }^{24}$ W. Kowalski, Echa wojny z lat 1879-1884: Boliwia żada od Chile dostepu do Pacyfiku, https:// histmag.org/Echa-wojny-z-lat-1879-1884-Boliwia-zada-odChile-dostepu-do-Pacyfiku-5325 (dostęp: 17 VII 2016 r.).

${ }^{25}$ A desolate strip, „Sailors without a Sea” 2013, No. 7/12, s. 124-125. 
znaczenie dla sprawy, a udział w niej wzięli najlepsi boliwijscy prawnicy. Chile zaś miało niecały rok, aby przygotować swoją odpowiedź Trybunałowi - do lutego 2015 r. ${ }^{26}$ Przekonanie o słuszności roszczeń i zaangażowaniu w sprawę organizacji międzynarodowej stale towarzyszyło wypowiedziom Moralesa, w których niejednokrotnie mówił, że Boliwia ma zaufanie do trybunałów międzynarodowych. Jednak w efekcie Międzynarodowy Trybunał Stanu w Hadze nie przyznał racji Boliwii i orzekł, że nie jest władny rozstrzygać sporów terytorialnych ${ }^{27}$.

Obecnie rozwiązanie problemu odzyskania dostępu Boliwii do terenu morskiego nie jest proste. Obustronne szukanie porozumienia przez oba kraje wydaje się rzeczą konieczną. Jednak rozmowy po objęciu funkcji prezydenta Chile przez Sebastiana Pinerę znalazły się w martwym punkcie. Upatrywano nadziei, że w kolejnych wyborach, kiedy zmieni się prezydent, spór odżyje. Trzeba także mieć na uwadze to, że prezydent Boliwii Evo Morales głęboko wierzy w korzystne i pokojowe rozwiązanie sprawy. Zapewniał też, że Boliwia stanowi kontynent pokoju bez wojen i szuka pokojowych rozwiąań historycznych niesprawiedliwości. W wystapieniach Morales często porównuje propozycje dyktatora Chile Augusto Pinocheta odnośnie do utworzenia dla Boliwii dostępu do morza w latach siedemdziesiatych XX w. i wierzy, że obecny rzad demokratyczno-socjalistyczny spełni żądania boliwijskie w XXI w. ${ }^{28}$ Te słowa Moralesa skierowane były do współczesnej prezydent Chile Michelle Bachelet. Morales twierdzi też, że żaden kraj nie powinien być pozbawiony dostępu do morza przy gwarancji, że Boliwia pragnie tego, aby „morza należały do wielu narodów - narodu chilijskiego, boliwijskiego i peruwiańskiego" 29 .

\section{Współczesny spór Boliwii z Chile o dostęp do terenu morskiego}

Upór Boliwii w sprawie odzyskania dostępu do obszaru morskiego nie jest niczym dziwnym. Trzeba zauważyć, że Boliwia wraz z Paragwajem należą do najuboższych państw regionu. Zatem dostęp morski miałby duży wpływ na polepszenie ich geopolitycznego sta-

\footnotetext{
${ }^{26}$ C. Gouverneur, op. cit., s. 32-35.

27 T. Skowronek, op. cit., s. 1-2.

28 Ibidem, s. 5-6.

${ }^{29}$ K. Zaczkow s ka, Boliwia będzie walczyć o dostęp do Pacyfiku, http:/ /www. psz.pl/132-ameryka-poludniowa/boliwia-bedzie-walczyc-o-dostep-do-pacyfiku (dostęp: 17 VII 2016 r.).
} 


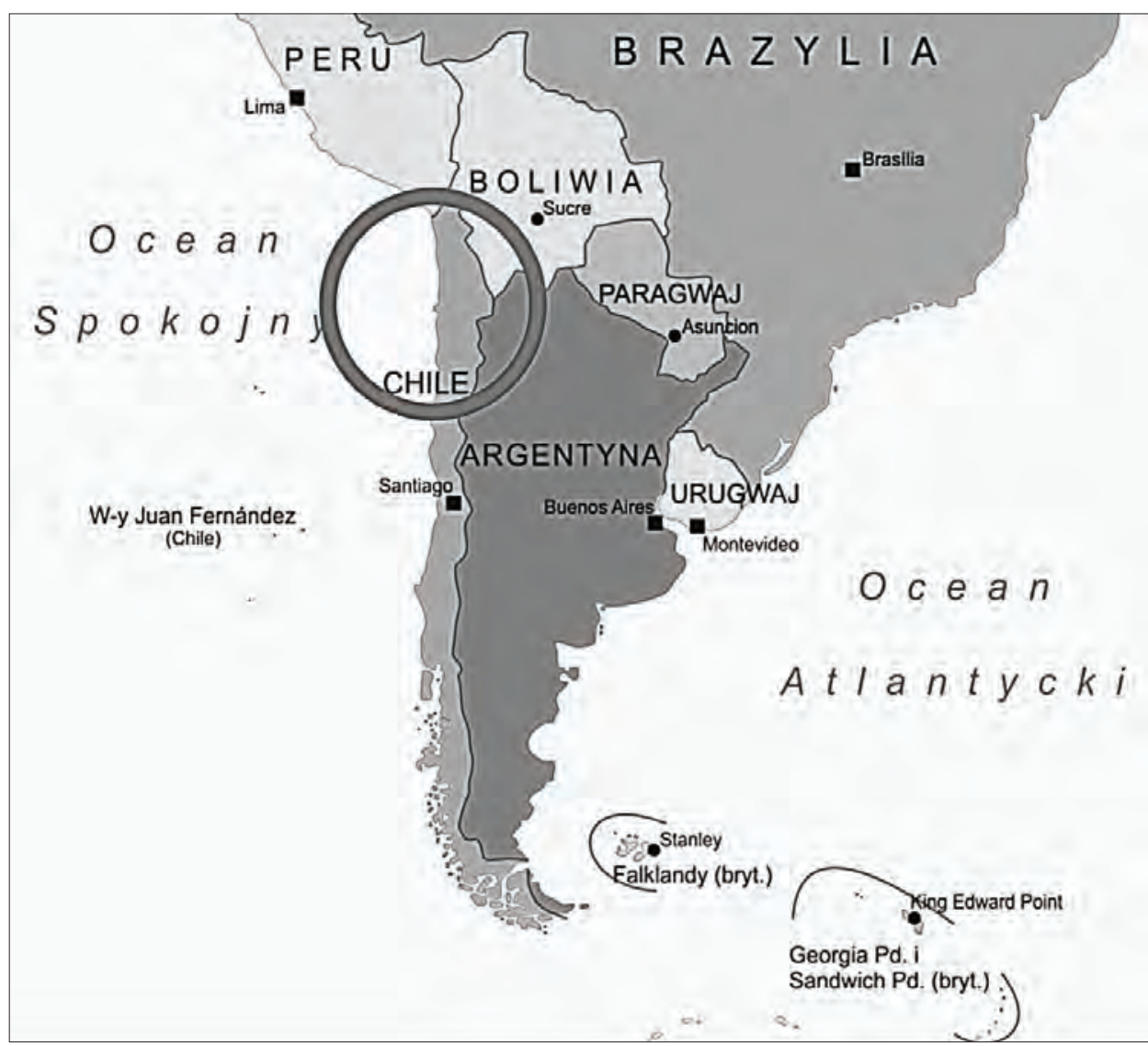

Współczesny spór Boliwii z Chile o dostęp do terenu morskiego (Źródło: opracowanie własne na podstawie: https://pl.dreamstime.com/ fotografia-stock-ameryka-poudniowa-administracyjna-mapa-image29108622)

tusu. Ułatwiłby również eksport towarów oraz produktów na nowe rynki zbytu. Należy też stwierdzić, że Chile stoi w lepszej sytuacji przetargowej, gdyż ma większy potencjał ekonomiczny, polityczny i militarny niż Boliwia. Analitycy zatem zakładają, że naród boliwijski jest $z$ góry skazany na porażkę. Wyrok Międzynarodowego Trybunału Sprawiedliwości w Hadze z 2015 r., o którym wspomniano, odrzucił zastrzeżenia Chile do żądań Boliwii. Trybunał nie poczuł się kompetentny, by rozpatrzyć spór graniczny między dwoma krajami, wywierając zarazem presję na Chile do negocjacji z rządem Boliwii. Opowiedział się zatem za klasycznym rozwiąaniem typu „rozwiązujcie sami swoje problemy”, co na ogół charakteryzuje relacje "sąsiedzkie". 


\section{Marynarka Wojenna Boliwii}

Boliwia ma trzy rodzaje sił zbrojnych: siły powietrzne, wojska lądowe oraz marynarka wojenna. Uzbrojenie sił lądowych w 2014 r. składało się z 54 czołgów, 211 opancerzonych pojazdów bojowych i 86 zestawów holowanej artylerii. Marynarka Wojenna Boliwii liczyła wówczas 19 okrętów obrony wybrzeża, a jej siły powietrzne w 2014 r. uzbrojone były w 42 samoloty szkolno-bojowe, 30 transportowych i 20 śmigłowców. Armia Boliwii w 2014 r. składała się z 55,5 tys. żołnierzy zawodowych oraz z 37,1 tys. rezerwistów. Ranking „Global Firepower” z 2014 r. umieścił siły zbrojne Boliwii na 91 pozycji sił militarnych świata, $z$ rocznym budżetem przeznaczonym na cele obronne ok. 315 mln dolarów ${ }^{30}$.

Działalność Marynarki Wojennej Boliwii jest regularnie upamiętniana. Jest to widoczne zwłaszcza podczas okolicznościowych imprez organizowanych przez władze, spotkań, konferencji i innych obchodów. Co roku w dniu 23 marca Boliwijczycy wychodza na ulice La Paz, aby upamiętniać Dzień Morza - święto Marynarki Wojennej. Ich marszowi przez ulice miasta $z$ modelami statków i zdjęciami oceanu towarzyszy parada marynarki boliwijskiej. Jest to dość zaskakujący widok dla turystów w kraju, który nie ma dostępu do morza grubo ponad wiek. Interesujace jest to, że Boliwia nie jest jedynym krajem, który ma swoją Marynarkę Wojenną bez dostępu do morza. W podobnej sytuacji sa Uganda, Laos i Rwanda w Afryce, a także Kazachstan, Serbia i Paragwaj. Okręty Marynarki Wojennej Boliwii stacjonuja na jeziorze Titicaca, które jest najwyżej położonym jeziorem żeglownym i największym akwenem wysokogórskim świata ${ }^{31}$. Flota wojenna Boliwii jest utrzymywana na rzekach o długości 5 tys. mil, stanowiących dopływy Amazonki ${ }^{32}$.

Załogi okrętów Marynarki Wojennej Boliwii zajmuja się przede wszystkim zwalczaniem przemytu, narkobiznesu, a także dostawa zaopatrzenia do odległych obszarów wiejskich. Organizują również akcje ratownicze ludzi i zwierząt w sytuacjach kryzysowych powodzi i klęsk naturalnych. Władze Boliwii sa przekonane, że Mary-

${ }^{30}$ Current military capabilities and available firepower for 2016 detailed, http://www.globalfirepower.com/country-military-strength-detail.asp?country_id= Bolivia (dostęp: 17 VII 2016 r.).

${ }^{31}$ I. Trusewicz, Titicaca - trzynaście kilometrów, „Rzeczpospolita” 1997, nr 143 , s. 17.

${ }^{32}$ A. Kozłows ka, Nie tylko lamy i Titicaca, „Gazeta Wyborcza Gdańsk” 2008, nr 144, s. 8. 
narka Wojenna jest bardzo dobrze przygotowana do wyjścia na morze. Wzięła ona udział w wysłaniu łodzi patrolowych i w misji pokojowej ONZ na Haiti ${ }^{33}$. Odkad prezydentem Boliwii został Evo Morales, Marynarka Wojenna zacieśniła współpracę z siłami morskimi Wenezueli, która organizuje szkolenia oficerskie ${ }^{34}$.

Dni Morza stanowią dogodna okazję dla upamiętnienia utraty przez Boliwię dostępu do Pacyfiku. Naczelny dowódca Marynarki Wojennej Boliwii Raúl Viscarra Escobar zapewnia o mobilizacji jej szeregów. W swych wystapieniach stale przypomina, że wbrew powszechnemu rozumieniu służba $\mathrm{w}$ tej jednostce nie jest ograniczona do noszenia munduru. Jest tu wymagana znajomość metod nawigacyjnych, które zapewniają personelowi armii umiejętność wypłynięcia w morze oraz sterowania okrętami ${ }^{35}$.

Co roku $z$ okazji wspomnianych Dni Morza w Boliwii organizuje się szereg spotkań w ośrodkach edukacyjnych całego kraju według wytycznych Naczelnego Dowódcy Sił Zbrojnych i Ministerstwa Obrony. Udział w nich biora członkowie niemalże wszystkich jednostek wojskowych. Przy okazji promuje się rozmaite inicjatywy, typu program „Niebieskie Serca”, który ma się przyczynić do wzrostu świadomości morskiej wśród dzieci i młodzieży. Na jednym ze spotkań zaprezentowano projekt ustawy odnoszącej się do interesów morskich Boliwii, a także kwestii dotyczacych opadów i zbiorników wodnych. Mowa była o zapewnieniu sprawnego zarzadzania zasobami Boliwii i wsparciu działań w kierunku zrównoważonego rozwoju kraju ${ }^{36}$.

Oficjalnym celem Marynarki Wojennej jest zagwarantowanie suwerenności oraz obrony interesów na rzekach i jeziorach. W przypadku marynarki Boliwii będzie ona zachowana, gdyż władze, wojsko i cały naród wierzą w to, że dzięki upamiętnianiu tradycji morskiej kraj ich w końcu odzyska dostęp do morza. Zatem La Fuerza Naval Boliviana funkcjonuje po to, żeby w pełni podtrzymywać ową nadzieję. Boliwijczycy sa przekonani, że morze im się prawnie należy, w związku z czym mają oni obowiązek je odebrać.

${ }^{33}$ S. Farber, Wolne Haiti - strach przed wolnościa, „Monde Diplomatique - miesięcznik społeczno-polityczny" 2016, nr 3, s. 36-37.

${ }^{34}$ A. Main, Wenezuela - wywrotowe pokusy i zakusy. Rewolta uprzywilejowanych, „Monde Diplomatique - miesięcznik społeczno-polityczny” 2014, nr 4, s. 8-9.

35 J. Parzuchowska, Boliwijska marynarka gotowa do powrotu na morze, „Biuletyn MSZ”, 3 III 2012, s. 2-3.

${ }^{36}$ Ibidem, s. 3. 
Poza Boliwijczykami dbajacymi o Marynarkę Wojenną nikt nie wierzy w szybkie rozwiązanie sprawy dostępu do morza. Jej osobliwość istnienia potęguje niepoważne traktowanie przez obcokrajowców marzeń marynarzy. Chilijczycy opowiadaja na ich temat dość niewybredne dowcipy. Mimo tej sytuacji, gdy nadchodzi 150 rocznica wojny saletrzanej, flota morska zyskuje na znaczeniu. Zaprzyjaźniony $z$ prezydentem Boliwii Evo Moralesem przywódca Wenezueli Hugo Chavez, wyszedł $z$ propozycja wsparcia finansowego w restrukturyzacji oraz szkoleniu boliwijskich sił morskich ${ }^{37}$.

Szanse na dojście do porozumienia w sprawie odzyskania dostępu do terenu morskiego Boliwii sa nikłe. Rozmowy sa co prawda $\mathrm{w}$ toku, ale wciąż nie zachodzą konkretne zmiany. Tych opinii nie podzielaja Boliwijczycy przekonani w swej dumie narodowej o sukcesie. Prezydent Boliwii Evo Morales, podobnie jak jego poprzednicy, często występuje na tle mapy przedstawiającej granice Boliwii sprzed 1879 r., tj. sprzed wojny o saletrę. Ponadto w skład jego kompanii reprezentacyjnej wchodza marynarze ubrani $\mathrm{w}$ białe mundury. Dla składającej się z 5 tys. ludzi Marynarki Wojennej uregulowanie krzywd historycznych jest sprawa honoru. Trzeba dodać, że jednostka ta nie narzeka na brak zajęcia. Oprócz obszernych wód jeziora Titicaca Boliwia ma 8 tys. km rzek, które sa przez Marynarkę patrolowane. Zajęciem preferowanym przez jednostkę oprócz nadmienionych jest penetracja wraz $z$ archeologami jeziora w poszukiwaniu inkaskich ruin.

\section{Podsumowanie}

Zabiegi o odstapienie terenu morskiego dla Boliwii stanowia jeden z ważniejszych priorytetów i punktów zapalnych z Chile. Mimo że od wojny minęło 136 lat, kwestia dostępu do terenu morskiego dla Boliwii nie została rozwiązana. Od 2005 r. wielokrotnie sprawy te usiłował uregulować prezydent Boliwii Evo Morales. Jego próby domagania się na forum międzynarodowym zrewidowania granic Boliwii i Chile kończyły się klęską. Przez wiele lat próbowano rozmaitych metod dyplomatycznych i starano się rozwiazać ten problem $z$ Chile także w wyniku bezpośrednich negocjacji. Optymistycznie rokowało utworzenie specjalistycznej grupy, która miała doprowadzić do przywrócenia relacji dyplomatycznych Chile-Boliwia, choć nie ma konkretnych efektów w tym zakresie.

${ }^{37}$ A. Main, op. cit., s. 8-9. 
Nieograniczony dostęp do terenu morskiego Boliwii wiąże się $z$ dużymi możliwościami rozwiniętego handlu i powstania bazy turystycznej. W obecnych czasach saletra nie odgrywa już tak istotnej roli, więc ważną kwestią jest też dostęp do swobodnego rybołówstwa. Jednym $z$ miejsc współczesnego wydobywania saletry jest miasto Tocopilla, choć jej pozyskiwanie nie jest tak zyskowne ${ }^{38}$. Nawet poparcie starań o dostęp do obszaru morskiego Boliwii przez Wenezuele i Peru nie pomaga w postrzeganiu polityki chilijskiej $\mathrm{w}$ tej kwestii jako lawirowania i omijania tematu w oficjalnie stonowanych stosunkach $z$ Boliwią. Taki stan rzeczy potwierdza zwrócenie się Boliwii o rozwiązanie sprawy przez Międzynarodowy Trybunał Sprawiedliwości w Hadze.

Biorąc pod uwagę, że Boliwia jest najuboższym krajem Ameryki Południowej, nie może ona rozwiązać kwestii dostępu do morza w sposób siłowy. Od chwili uzyskania przez kraj niepodległości jego armia ponosiła w konfliktach same klęski. Efektem tego była utrata przez Boliwię około 1/3 swojego obszaru, głównie na rzecz Paragwaju i Chile. Politycznie wystapienia dyplomatów Boliwii sa w obecnej sytuacji międzynarodowej mało słyszalne ${ }^{39}$.

Odpowiedź, czy rozwiązanie sporu i przywrócenie terenu morskiego Boliwii jest obecnie możliwe, nie jest prosta. Mając jednakże na względzie rzeczywisty stan rzeczy i sytuację panująca $\mathrm{w}$ obu krajach, w najbliższych latach nie zanosi się na jakieś radykalne zmiany.

Konflikt o saletrę w latach 1879-1884 jest najdłużej ciagnącym się sporem na świecie. Przez 136 lat zdołał on przetrwać kilka pokoleń, aby nadal tkwić w swej pierwotnej formie. Co prawda Międzynarodowy Trybunał Sprawiedliwości w Hadze stwierdził, że Chile musi oddać Peru teren morski, ale $z$ zachowaniem pasa przy brzegu. Jednakże nie ma decyzji w sprawie Boliwii.

W chwili obecnej Boliwia jest zmuszona przewozić swoje towary eksportowe przez tranzyt przez inne kraje, co stanowi dla niej znaczne utrudnienie, zwłaszcza patrzac $z$ perspektywy Ameryki Łacińskiej, w której dostępu do terenu morskiego oprócz Boliwii nie ma tylko Paragwaj. Rozwiązanie sporu dałoby zatem możliwość dynamicznego rozwoju gospodarki Boliwii i zakończyło spór nad-

${ }^{8}$ A. Winiarczyk-Raźniak, Atacama-najbardziej sucha pustynia świata, [w:] Badania i podróże krakowskich geografów, t. IV, red. Z. Górka, J. Więcław-Michniewska, Kraków 2009, s. 60.

${ }^{39}$ C. Gouverneur, op. cit., s. 32-35. 
szarpujący jej relacje $z$ Chile. Zakończenie sporu byłoby tym bardziej istotne, gdyż Chile jest jedynym krajem, $z$ którym Boliwia nie ma dobrych stosunków.

\section{Bibliografia}

\section{Opracowania}

A desolate strip, „Sailors without a Sea” 2013, No. 7/12, s. 120-135.

Burr R., By Reason or Force: Chile and the Balancing of Power in South America 1830-1905, Berkeley-Los Angeles 1967.

Cholewińska K., Czy reindianizacja państwa jest możliwa? Etnocentryczne projekty we współczesnej Boliwii, „Ameryka Łacińska - kwartalny biuletyn informacyjno-analityczny” 2014, R. XXII, s. 74-86.

Farber S., Wolne Haiti - strach przed wolnościa, „Monde Diplomatique - miesięcznik społeczno-polityczny” 2016, nr 3, s. 33-47.

Fijor J.M., Boliwia już czerwona, kto następny?, „Najwyższy Czas! - pismo konserwatywno-liberalne" 2003, nr 47, s. XX-XXI.

Gouverneur C., Boliwia zapatrzona $w$ morskie fale - 136 lat konfliktu, „Monde Diplomatique - miesięcznik społeczno-polityczny” 2015, nr 10, s. 31-44.

Kozłowska A., Nie tylko lamy i Titicaca, „Gazeta Wyborcza Gdańsk” 2008, nr 144, s. 7-8.

Kula M., Anatomia rewolucji narodowej. Boliwia w XX wieku, Wrocław 1999.

Kułak P., Międzynarodowy Trybunał Karny, „Annales Universitatis Mariae Curie-Skłodowska. Sectio K - Politologia” 2008, vol. XV, z. 1, s. 37-55.

Main A., Wenezuela - wywrotowe pokusy i zakusy. Rewolta uprzywilejowanych, „Monde Diplomatique - miesięcznik społeczno-polityczny” 2014, nr 4, s. 4-14.

Parzuchowska J., Boliwijska marynarka gotowa do powrotu na morze, „Biuletyn MSZ", 3 III 2012, s. 1-10.

Ronald B., The Bolivia-Chile-Peru Dispute in the Atacama Desert. Boundary and territory briefing, vol. I, No. 6, Durham 1994.

Sater W., Chile and the War of the Pacific, Nebraska 1986.

Sierpowski S., Narodziny Ligi Narodów, Poznań 1984.

Skowronek T., Boliwijska walka o dostęp do oceanu, „Biuletyn Europejskiego Centrum Analiz Geopolitycznych", 4 V 2013, s. 1-13.

Talbott R., A History of the Chilean Boundaries, Ames 1974.

The Blue Book. The Maritime Claim of Bolivia, Presidency of the Republic, Ministry of Foreign Affairs, Dirección de Informaciones de la Presidencia de la República, [b.m.] 2004.

Traczyk A., Analiza: Boliwia u progu trzeciej kadencji Evo Moralesa, „Global.Lab” 2015, nr 2 (luty), s. 2-8. 
Traczyk A., Boliwia - zastygła rewolucja?, „Dziennik Opinii” 2016, nr 50, s. 2-11. Trusewicz I., Titicaca-trzynaście kilometrów, „Rzeczpospolita” 1997, nr 143, s. 16-18. Winiarczyk-Raźniak A., Atacama - najbardziej sucha pustynia świata, [w:] Badania i podróże krakowskich geograföw, t. IV, red. Z. Górka, J. Więcław-Michniewska, Kraków 2009.

Wordliczek R., Ewolucja w stosunkach boliwijsko-amerykańskich na przełomie XX $i X X I w$., "Ameryka Łacińska - kwartalny biuletyn informacyjno-analityczny” 2015, R. XXIII, nr 2, s. 66-90.

\section{Netografia}

Current military capabilities and available firepower for 2016 detailed, http: / /www. globalfirepower.com/country-military-strength-detail.asp?country_id=Bolivia (dostęp: 17 VII 2016 r.).

Kowalski W., Echa wojny z lat 1879-1884: Boliwia żada od Chile dostępu do Pacyfiku, https:// histmag.org/Echa-wojny-z-lat-1879-1884-Boliwia-zada-od-Chiledostepu-do-Pacyfiku-5325 (dostęp: 17 VII 2016 r.).

Zaczkowska K., Boliwia będzie walczyć o dostęp do Pacyfiku, http://www.psz. pl/132-ameryka-poludniowa/boliwia-bedzie-walczyc-o-dostep-do-pacyfiku (dostęp: 17 VII 2016 r.). 